\title{
Poetry, physiology, and puerperal fever: Understanding the young Oliver Wendell Holmes*
}

\author{
Constance E. Putnam
}

The Wellcome Trust Centre for the History of Medicine at UCL, Euston House, 24 Eversholt Street, London NW1 1AD, United Kingdom

Received: September 26, 2001

Accepted: October 24, 2001

The 19th-century American physician Oliver Wendell Holmes (1809-1894) is known, internationally, more for his literary output than for his contributions to medical science. Yet a single paper he wrote in 1843 - "The Contagiousness of Puerperal Fever" - has made him a hero in the eyes of many (especially in the United States) of the struggle against that scourge. Why that one article, written when Holmes was still in his thirties, should - even in its expanded 1855 version - so routinely be referred to as a "classic of medical literature", and why its author should have been raised on such a high pedestal that some grant him a position beside Ignác Semmelweis, are complicated questions. This present paper is an attempt to begin assessing what it is that makes someone a medical hero by looking at three different aspects of Holmes's early career. He was even as a young man a poet and a physiologist/anatomist as well as the author of this important essay. Whether and how those three features of Holmes's many-sides public persona are connected is discussed as a prelude to considering whether his work on puerperal fever legitimates his status as a medical hero. heroes

Keywords: Holmes, Oliver Wendell, Semmelweis Ignác Fülöp, puerperal fever, medical

\footnotetext{
* A preliminary version of this paper was presented in a seminar for the Wellcome Trust Unit for the History of Medicine at the University of Glasgow

Correspondence should be addressed to

Constance E. Putnam, Ph.D

111 Hayward Mill Road

Concord, MA 01742, USA
} 


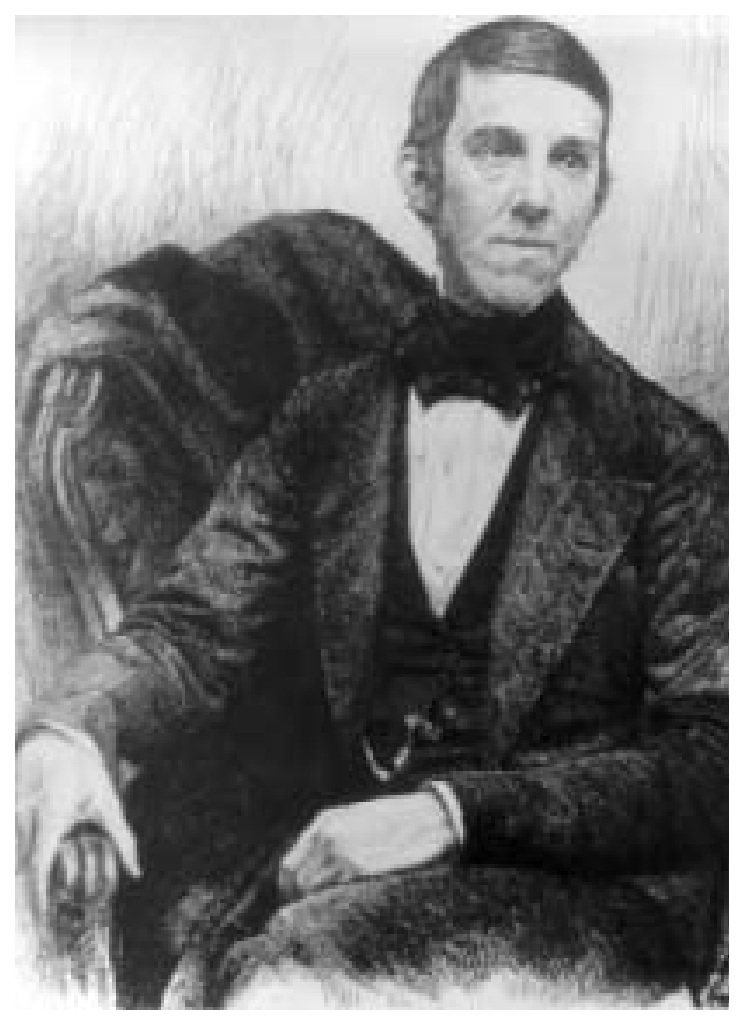

Oliver Wendell Holmes*

Most physicians and medical historians respond quickly when asked to name a single outstanding figure in the struggle to reduce the number of women dying of puerperal fever. "Ignác Semmelweis," they will say, naming the Hungarian physician whose work (initially at the Allgemeines Krankenhaus in Vienna, later at Szent-Rókus Kórház in Budapest) helped focus attention on the importance of having those who attend women in childbirth wash their hands. At least that is the name that will generally spring first to mind in all of Europe. In the United States, too, Semmelweis sits high on the list of pioneers in this field. Many American doctors and historians of medicine, however, will almost as promptly name Oliver Wendell Holmes as well. To those outside the United States this is puzzling; Holmes, if known at all, is thought of first as a poet or essayist on non-medical subjects, and second as a medical professor.

\footnotetext{
* The portrait of OW Holmes is published by courtesy of the Wellcome Trust Library (London)
} 
Nonetheless, it remains true that of the many concerned physicians desperate to reduce the mortality rate from puerperal fever among their obstetrical patients, it is the Hungarian Ignác Fülöp Semmelweis and the American Oliver Wendell Holmes who are most frequently associated in medical histories with the "discovery" of the ætiology of the disease and the most effective prophylaxis. In their day, the disease was fatal with frightening frequency, leaving little reason or room to discuss cures as such.

The standard version of the puerperal fever story is a simple tale where first ignorance rules and where, eventually, the sheer power of truth overwhelms the (invidious) traditionalists who refuse to acknowledge that they might be mistaken. Reducing the story (unfairly) to an account of efforts by Semmelweis and Holmes is a further oversimplification. Serious historians who have looked closely at the subject agree (33): Doctors did not suddenly begin to wash their hands after Holmes published his essay when they had not done so before, nor did puerperal fever disappear when they did wash their hands - as Semmelweis, to his dismay, had to acknowledge.

Among all the many physicians who wrote on puerperal fever throughout the nineteenth century, why should Holmes and Semmelweis have been singled out for their pioneering efforts? Answering this question is part of what I hope to explore in a longrange project I have recently begun (34). Another part of the project is why two such very different men, with two such very different careers, have come to share the limelight on this particular stage. That they share it uneasily - and unevenly - is evidenced by the fact that the full story of Holmes and Semmelweis and their work on this topic has never been told in an adequately comparative-contrastive manner.

Medical historians and other writers have tended either to discuss only one of these two doctors or to give exceedingly brief accounts of their work. An example of the latter is Irvine Loudon's treatise Death in Childbirth, where he devotes fewer than a dozen pages to each of these two men (29). An example of the former is K. Codell Carter's introduction to his translation of Semmelweis's great work (38), in which he deals with Holmes in less than three of the fifty-five pages (4). Other writers, too, choosing to focus on one of the two men, then mention the other as a kind of afterthought. In Landmarks in Science, for example, Robert B. Downs ends a six-page chapter on Holmes with a single short paragraph on Semmelweis (9). Writers who have looked at Holmes and Semmelweis together have typically focused on the priority question, as, for example, Gerald Weissmann did in his aptly named "Puerperal Priority" (43). [Others, like György Gortvay and Imre Zoltán, in their very helpful study of Semmelweis, have treated the priority issue both more thoroughly and more as the aside it is (11)].

Semmelweis's tale is both easier and harder to tell than Holmes's: easier because less multifaceted, with the various threads more of a piece - as if twisted neatly together into a single thick rope; harder, because Semmelweis certainly a less public individual 
who seems to have been at least superficially much less successful. Describing his career accurately presents major challenges, as the work of other historians has made clear. In case of Holmes, as a very preliminary step toward understanding why his work in this arena - a single essay - should even be mentioned alongside that of Semmelweis, I have set myself the task of answering three questions: What if any connection is there between Holmes's reputation as a poet (and writer more generally) and his work on puerperal fever? Is there any significance for the puerperal fever story in the fact that Holmes was a medical school professor first of physiology and later (and longer) of anatomy? Why is it that he has been included in the pantheon of those who began the conquest of puerperal fever? My hope is that the attempt to answer these and other questions will pave the way to using the Holmes-Semmelweis story as a case study to illuminate two larger issues of general importance: the transmission of medical knowledge and the making of medical heroes.

It is not failure to appreciate Holmes and Semmelweis that has sparked my interest, for they have not been ignored. Rather, it is my belief that there are further lessons to be learned from comparing (contrasting) the sociopolitical, intellectual, and cultural contexts for the lives and work of these two physicians. I anticipate that the stories of Holmes and Semmelweis and their completely independent efforts to spread the word on the ætiology and prevention of puerperal fever, if examined together, will produce further insights into the two general issues mentioned above that are of central concern to me. Why it matters that we understand how medical knowledge is transmitted - or, as some would prefer, how medical information becomes medical knowledge - should be self-evident. How this transmission, or transformation, connects with the way medical heroes emerge or are constructed is therefore perhaps the more interesting issue. But both that and the extent to which I am right that the HolmesSemmelweis pairing can be used in the way I have proposed remains to be seen. I predict the cross-cultural nature of my larger study is what will set it apart.

The basic story of Semmelweis's work and career is too well known to readers of this journal to need rehearsing here (though I will of course eventually review it in my larger study). Despite all that has been written and said about this figure of towering importance, however, there is still need for an account that is both fuller than the best we have to date and more dispassionate than the severest revisionist and the most extravagantly adulatory versions of the story (28). Among the best accounts in English is the chapter on Semmelweis in Irvine Loudon's new book, The Tragedy of Childbed Fever. Loudon has done a fine job of summarizing the story (though not all will be pleased with his very sober assessment), and I remain convinced it is a tale that can sustain our interest for more than the twenty pages he devoted to it. A hint that Loudon would agree with is in the way he identifies the nature of the "Semmelweis problem" in the opening of his chapter on the man: 
(Semmelweis) is often described as a misunderstood martyr, driven insane by the united, stupid, and implacable opposition of his contemporaries, who refused to accept or implement his doctrines. This picture of Semmelweis began to be constructed some twenty-five years after his death, and in a short time he was glamorized and presented as genius and hero. In fact, many of the above attributions turn out to be untrue, and the real story of Semmelweis is much more interesting than the traditional hagiographic version (30).

The other sense in which even the best accounts of Semmelweis's life and career are not so full as they could be, and need to be, is illustrated by the degree to which writers have focused on the "mystery" that cast a shadow on his biography (was he truly mad? why was the truth withheld so long?) - especially having to do with his final, fatal illness. Although István Benedek has made valuable contributions, clearing up important details, by writing an entire book on that final illness he, too, emphasized the "mystery" part of the story and left much of interest unsaid (3). Georg Silló-Seidl's Die Wahrheit über Semmelweis (40) - another careful exploration of Semmelweis's story-looks at many of the things that interest me, but this author's focus is also on the Semmelweis "problem" or "mystery" and is accessible only to those who read German or Hungarian.

Questions can be (and have been) raised as to whether Semmelweis was his own worst enemy. Did he cause problems for himself by failing to understand that truth is often not enough? or by not undertaking in appropriate and timely fashion to publicize his work? Some think the answer is simple. Seventy years ago, Howard W. Haggard opined that "If Semmelweis had wielded the pen of Oliver Wendell Holmes his great discovery would have been adopted throughout Europe in the first twelve months after it was made" (12). Claims of this sort are precisely part of what I am trying to establish or debunk, whichever proves necessary - but it is clear that "what-ifs" hang in the air.

A bit of background on Holmes will help prepare the ground for the seeds of the theory I wish to cultivate. Oliver Wendell Holmes, born on 19 August 1809, was very much a product of New England: Born in Cambridge, Massachusetts, he died across the Charles River in Boston eighty-five years later (on 7 August 1894). "Wendell" (as he was called) was apparently expected to follow in the footsteps of his father, the Rev. Abiel Holmes, minister of Cambridge's Congregational Church. But a look at Venus through a telescope set up on Cambridge Common seems to have provoked in the young boy the kind of questioning that "did not make a theologian." Besides, a "world that contained cigars, wines, cider, and women was much to be preferred to one that was dominated by the works of Jonathan Edwards (a New England divine who preached that human beings are fallen wretches at the mercy of an angry God)" (25). 
When it came time to choose a profession after taking his first degree at Harvard, for reasons that no one seems now to know, Holmes chose the law. Apparently not much taken with legal studies, he began more earnestly to write poetry - something he had been doing sporadically for years (though his poems generally were published anonymously). He soon switched to medicine, first at Harvard and then in Paris, where he came under the influence of Pierre-Charles-Alexandre Louis. When Holmes returned to Boston, he began to practice medicine in a modest way; whether he did so desultorily or just unsuccessfully is open to interpretation. Somewhat curiously, although Holmes was a member of the Harvard Medical School faculty for thirty-six years (during part of which time he also served as dean), today his fame rests more on his literary contributions than on his medical career.

Holmes was a bit of an eccentric, in a society where that was rarely an asset. He did not conform to others' ideas of how he should behave or what should interest him. One of his biographers says that "he had been criticized for speaking of subjects which he had not properly studied, for borrowing so freely from others, for not being original" (41). A little man - he stood less than 1.60 in his stocking feet - he was by all accounts nonetheless a giant in literary and social arenas. He loved performing, both literally on a public stage (declaiming and sometimes singing his own poetry, or lecturing on a wide range of topics) and in private drawing-rooms or clubs (where he almost usually charmed his auditors). At the time of his death, he was known less as a physician than as a poet, biographer, novelist, lecturer, and as "the greatest conversationalist in the English language since Dr. Johnson (after whom, incidentally, he consciously modelled himself)" (25). Holmes the physician was, in other words, also a man about town.

We turn now to examine three incarnations of Holmes: poet, physiologist, and protagonist in the puerperal fever.

\section{The Poet}

Holmes's earliest writings of any significance were poems, and since a large part of his reputation has always rested on his contributions to occasional poetry, I will focus here on this aspect of his literary output. All accounts of Holmes's life give the distinct impression that virtually from boyhood on, Holmes was someone who could not stop himself from rhyming and punning. One early example that biographers like to quote comes from when he was still a teenager (25). Sitting outside, reading a newspaper, he was accosted by a hungry tramp passing by. Instead of simply sending the man to the kitchen door to speak to the maid, Ann, or going with him to the kitchen door, young Holmes tore a piece off his paper, wrote a note that he handed the man, and then sent him to Ann. The note read: 
Charitable Ann-

Give this poor man-

As much as you can-

A little meat,

And bread to eat,

And a shady seat-

Sometimes it must have seemed that Holmes thought in rhyme or in clever phrases. Throughout his life, he was famous for his quick quips and mots justes, though his first efforts on the lecture circuit left something to be desired. Not only was his speech somewhat halting; he often lost his train of thought. "His affinity for puns and wordplay sometimes got him off the track altogether," we are told (25).

In medical circles, one of the most frequently quoted of Holmes's quips was inspired by the situation of a medical school professor who found himself assigned to teach numerous subjects. Such a person, said Holmes, did not hold a professorial chair, but rather a settee. Though Holmes said this about the Swiss physiologist Albrecht von Haller (14), the witty remark has frequently been reported to have been made about any number of others (Nathan Smith - the founder of Dartmouth Medical School, John Warren at Harvard Medical School, Holmes himself) (35).

Once Holmes began to sign his poems and word got around what a lively speaker he could be, the requests flooded in for him to give after-dinner speeches or to write poems for special occasions. He nurtured his own reputation and the demand for new creative efforts by repeatedly saying he would write no more verse (or anything else non-medical) so that he could devote himself to medicine. Among the reasons seems to be that he feared he might not be taken seriously as a man of science. Being known as a wit was not advantageous: "When he said that the smallest fevers were thankfully received, the people who had no fevers laughed, but the people who had them preferred some one who would take the matter more seriously than they thought this lively young joker was likely to do" (32). One biographer insists that Holmes's "renown as a poet worked against him as a private physician" (25), and Holmes himself said as much later: "It is often a disadvantage to a young practitioner to be known for any accomplishment outside of his profession" (21). In other words, Holmes acknowledged indirectly that writing had at times distracted him from other professional pursuits (15).

An early poem initially signed simply "H." is one that has remained among Holmes's most famous. Written in 1836 in the heat of passion, "Old Ironsides" was penned overnight in response to a news report that the famous American warship of that name was perhaps to be scrapped. Much of Holmes's poetry today seems dated [a poet of his time, he wrote with florid sentimentality (17)], no one in American circles is likely to give a negative critique to this one: 
Ay, tear her tattered ensign down!

Long has it waved on high,

And many an eye has danced to see

That banner in the sky;

Beneath it run the battle shout,

And burst the cannon's roar; -

The meteor of the ocean air

Shall sweep the clouds no more.

Her deck, once red with heroes' blood,

Where knelt the vanquished foe,

When winds were hurrying o'er the flood,

And waves were white below,

No more shall feel the victor's tread,

Or know the conquered knee; -

The harpies of the shore shall pluck

The eagle of the sea!

Oh, better that her shattered hulk

Should sink beneath the wave;

Her thunders shook the might deep,

And there should be her grave;

Nail to the mast her holy flag,

Set every threadbare sail,

And give her to the god of storms,

The lightning and the gale! (18)

Poetry was not all Holmes wrote. It was while he was still studying medicine, in 1831, that he first used the title "The Autocrat of the Breakfast Table" for one of his essays (25). This would prove to be a forerunner of the essays (later published in book form) for which Holmes today is probably best known outside the United States. For his countrymen, too, both then and now, Oliver Wendell Holmes was "The Autocrat of the Breakfast Table." Indeed, one commentator has argued that the "distinctive mark of the Autocrat and its fellows (others in the "breakfast table" series included The Professor at ... and The Poet at ...) was ... the frank dominance of the author's personality" (37).

Holmes wrote novels, too, of no great interest today except in a study of what might be characterized as early "psychological" novels. Medical essays also flowed from Holmes's pen. Since one of them in particular - on puerperal fever - is the focus of another section below, I will say little here about this part of Holmes's output except 
to point out that he three times took home a Boylston Prize Medal, given to the winner of a prestigious local contest for medical essays. Having won in 1836, he submitted two essays the following year (one on each of the two assigned topics) and won in both categories. "Winning three prizes of this kind was a quick path to professional distinction," we are told (41). Holmes was not, however, the first to do so. George Cheyne Shattuck, for instance, had likewise garnered one prize one year and both prizes the next, three decades earlier (39). Also like Shattuck, Holmes published the three essays together in a neat little volume (14); it appeared almost at the same time as his first book of poetry. Thus while he was establishing his reputation as a poet, he was also establishing himself as a medical man; the Boylston essays book was widely reviewed (25).

\section{The Physiologist}

Just as Holmes was not only a poet, but a writer in several genres, he was also not merely a physiologist. Like most nineteenth-century physicians, he was not at all what we would think of today as a medical specialist. Though one of Holmes's express purposes in travelling to Paris was to study under Louis, revered particularly as a pathologist, when he and Jacob Bigelow founded the Tremont Medical School in Boston, Holmes began teaching physiology as well as pathology. Together with David Humphreys Storer and Edward Reynolds, Bigelow and Holmes offered a more systematically ordered curriculum than was usual at the time; each of the four doctors taught in only two subject areas. Anatomy, often paired with physiology, was handled instead by the professor of surgery (25).

Though it is often said that when Holmes was hired to teach at Dartmouth Medical School it was as professor of anatomy and physiology - which, as already indicated, would certainly have made sense - his actual position there is rather less clear. The Trustees Records at Dartmouth College explicitly tell us otherwise. At the annual meeting of 1838, the trustees "Voted by Ballot and chose Oliver Wendell Holmes Professor of Anatomy," following which they "Voted by Ballot and chose Elisha Bartlett Professor of Physiology, Medical Jurisprudence, \& Materia Medica" (42). But the picture of Holmes as Professor of Anatomy and Physiology persists, in part because of still-extant lecture admission tickets that read "Lectures on Anatomy \& Physiology, Oliver W. Holmes Professor" (6).

Furthermore, when Holmes began his two-year stint of teaching at Dartmouth the following autumn, in August 1839, he opened his "First Introductory Lecture" sounding very much as if he were the professor of both: "The branches of Anatomy and Physiology are so naturally and closely connected that they have been separated by authors and instructors only on account of their extent and complexity," he said. He also 
referred to "the branches (plural - of medicine) which I am to teach" and insisted that it would be his "general intention to make (the) two subjects keep pace with each other." Even the most difficult, isolated, anatomical facts could be learned, he insisted, if they were connected to the function of the part being learned. It would not be possible, he continued, "to follow the usual course adopted by lectures on pure physiology, for circumstances accidental in their nature must in some degree direct the order of our anatomical pursuits ..." (16). Indeed, throughout both that lecture and his "Second Introductory" a year later (in August 1840), he made repeated references to the close ties between anatomy and physiology (20).

So was this anatomy or physiology that Holmes was teaching? Either way, it is clear that he was convinced the various subjects to be studied overlapped and connected with each other. Not only did he insist that the general laws of matter needed to be understood and that the facts of physics and chemistry needed to be interwoven with those "properly belonging to physiology"; he stressed the importance of comparative anatomy and physiology. The convention of understanding anatomy and physiology to mean human structure and function troubled him: "In their larger sense they include the knowledge of the structure and functions of all living beings"; to teach only the human side of all this, he warned, would be erroneous: "we shall see that the isolated study of human anatomy and physiology would be utterly unphilosophical and unsatisfactory" $(16,20)$. [This view was not shared by everyone. The great TH Huxley later insisted that it was "a downright cruelty ... to require from gentlemen who are engaged in medical studies the pretence ... of a knowledge of comparative anatomy as part of their medical curriculum" (26)].

Holmes's "Second Introductory Lecture" was even less clearly focused on anatomy or physiology alone. Rather, it was a very general introduction to the study of medicine, which was quite appropriate; these opening lectures tended to be ceremonial, aimed at helping presumably eager students get a sense of what was to come and what they would be learning. The most striking feature of Holmes's two introductory lectures at Dartmouth is his enthusiasm for his subject, his desire to share a journey of exploration with his students. Lest these tyros be intimidated by what lay ahead, he painted a picture of the eminently possible: "Physiology, like anatomy, while it has been constantly gaining facts which might seem merely to increase the learner's labor, has at the same time gained so much light in the place of obscurity \& methods ... and is every day becoming vastly more easy of comprehension." Admitting he was new to the task of teaching, he closed the first lecture with the insistence that they were all "united as fellow-students of Nature" (16).

Holmes wanted his students to experience the excitement of learning all there was to know. At the beginning of that Second Introductory Lecture - perhaps having gained in confidence - the Holmes of poetic inclination took the floor first: 
How many mountains and valleys were to be crossed before you would be gathered together upon this tranquil plain, which the hills and the heavens have closed in as if for silence, for seclusion and for study!

Few places are more congenial to the pursuit of knowledge than this where we are brought together (20).

Later in the same lecture, he cautioned his auditors about what to expect:

Could I discharge my duty faithfully I should not pass over a system or structure or office of all this complicated living machinery. Yet in this elaborate detail of description there may be many things included without any direct practical bearing. No surgeon has yet been found bold enough to undertake the extraction of the sphenoid bone, yet it will be my duty to describe its holes and angles accurately and conscientiously. I cannot isolate things from the rational connexion so as to give only what is of obvious immediate necessity - and if I could do so, how would your ideas hold together without their proper bonds of union (20)?

In fact it is such rhetorical flights that distinguish this pair of lectures by Holmes more than their actual content. Harking back to the proud beginnings of the school founded in 1797 by Nathan Smith, to inspire the students, Holmes ended with an encomium to that local hero (without mentioning his name):

The voice of medical instruction was first heard in this half reclaimed wilderness in the accents of one whom our science regards as among the most honored of its patriarchs in New England. We may both take a lesson from him - the instructor to be always diligent in his office ...; the student to struggle manfully and cheerfully with all his early difficulties; for we cannot forget that he died ... with the grateful attachment and remembrance of half the profession among us, whom he had numbered as his pupils; nor that he left the humble labors of the fields, when a poor and unknown stripling to arrive by courage, industry, and intelligence at the fullness of honor and prosperity (20).

No wonder Dartmouth is happy to claim as a quondam member of its medical school faculty the man who could utter such pious and hortatory reflections on the medical school's founder.

But Holmes could be funny, too, as student reports of his regular course lectures make clear (5). He was a very popular lecturer. As one student recalled it:

He enters, and is greeted by a mighty shout and stamp of applause. Then silence, and there begins a charming hour of description, analysis, simile, anecdote, 
harmless pun, which clothes the dry bones with poetic imagery, enlivens a hard and fatiguing day with humor, and brightens to the tired listener the details for difficult though interesting study (32).

If Holmes's role as a physiology instructor at Dartmouth is a bit uncertain, an unambiguous claim that he was a physiologist could be made when he joined the faculty at Harvard Medical School in 1847, for there his appointment was explicitly to a joint professorship in anatomy and physiology. After 1871, however, he was no longer responsible for teaching physiology, and he seems to have been happy with the new arrangement. In his farewell address at Harvard a decade later, having observed that he had just completed his thirty-sixth course of lectures as Professor of Anatomy, he continued thus:

For more than half of my term of office I gave instruction in Physiology, after the fashion of my predecessors and in the manner then generally prevalent in our schools, where the physiological laboratory was not a necessary part of the apparatus of instruction. It was with my hearty approval that the teaching of Physiology was constituted a separate department and made an independent Professorship (15).

The increasing need to pay attention to basic science concepts in physiology courses may have dampened his enthusiasm. A couple of years later he made reference to this feature of the discipline: "Physiology is a new science, we might almost say, since the perfecting of organic analysis, the invention of the achromatic microscope, and of the numerous instruments of precision which record the vital actions and conditions" (13). Not that he disapproved, but his primary interests lay elsewhere. The memorial tablet to Holmes in Boston's King's Chapel fittingly refers to him as "Poet," "Essayist," and "Teacher of Anatomy"; there is no mention of physiology (24).

\section{The Protagonist in the Fight against Puerperal Fever}

By comparison with Ignác Semmelweis's magnum opus on puerperal fever - a tome of more than 500 pages written in often turgid German, published in 1861 (38) the paper Oliver Wendell Holmes read to the Boston Society for Medical Improvement early in 1843 was a minor work indeed. When published a few weeks later in the shortlived journal put out by that society (Holmes's essay appeared in the fourth and final issue of Vol. 1; there never was a Vol. 2), it took up little more than two dozen pages (22). One might think there was no contest, that there would therefore be no reason to mention Holmes's name in the same breath with that of the great Semmelweis. Indeed, as one of Holmes's many biographers has pointed out, "the Boston Society for Medical 
Improvement was a small private club of local physicians; however valuable its activities were to individual members, its doing were not likely to attract much attention outside Boston" (41).

But Holmes's "Contagiousness of Puerperal Fever" could hardly fail to make an impression on those who heard or read it. [The claims that the paper "was to shake the medical world of the time" and that the "medical journals of two continents (were) filled with critical abuses" of it are, however, hyperbolic (5)]. The essay, impassioned and vigorous, was what we today would call a review essay; unlike Semmelweis, Holmes had done no original work. Rather, he presented the profession with a detailed catalogue of cases he had culled from the literature or that had been reported to him by colleagues. Acknowledging that the information was not new, he denied that it was therefore not worth presenting:

It may be said that the facts are too generally known and acknowledged to require any formal argument or exposition, that there is nothing new in the positions advanced, and no need of laying additional statements before the Profession. But on turning to two works, one almost universally, and the other extensively appealed to as authority in this country, I see ample reason to overlook this objection .... It seems proper, therefore, to remind those who are in the habit of referring to these works for guidance, that there may possibly be some sources of danger they have slighted or omitted, quite as important as a trifling irregularity of diet, or a confined state of the bowels, and that whatever confidence a physician may have in his own mode of treatment, his services are of questionable value whenever he carries the bane as well as the antidote about his person.

The practical point to be illustrated is the following: The disease known as Puerperal Fever is so far contagious as to be frequently carried from patient to patient by physicians and nurses (23; emphasis in the original).

The statement was bold and unequivocal; Holmes was not timid in his use of language. He could, however, soften his tone when he sensed doing so might be advantageous: It is as a lesson rather than as a reproach that I call up the memory of these irreparable errors and wrongs. No tongue can tell the heart-breaking calamity they have caused; .... There is no tone deep enough for regret, and no voice loud enough for warning. The woman about to become a mother, or with her new-born infant upon her bosom, should be the object of trembling care and sympathy wherever she bears her tender burden, or stretches her aching limbs ... 
God forbid that any member of the profession to which she trusts her life, doubly precious at that eventful period, should hazard it negligently, unadvisedly, or selfishly (23)!

This initial presentation of Holmes's essay was not the end of the matter. (Had it been, the history of the whole subject might have quite different.) Leaving aside the small number of copies that Holmes had struck off for private distribution, some greater currency was given the essay when an abstract of it was printed in another journal (1). To that brief summary the profession did respond - perhaps unfortunately, for the abstract carried little of the rhetorical flourish and less of the argument than the original.

Enough controversy was aroused to keep the discussion going, but for reasons that are as yet not clear to me, it was 1855 - twelve years later - before Holmes picked up the torch again. [There is a curious parallel here to the fact that Semmelweis did not publish his book until roughly twelve years after he had made his seminal findings (38)]. When Holmes did re-issue his paper, he added a twenty-page introduction that carried even more passionate language. The ringing phrases still stir the heart today:

I take no offence, and attempt no retort. No man makes a quarrel with me over the counterpane that covers a mother, with her new-born infant at her breast. There is no epithet in the vocabulary of slight and sarcasm that can reach my personal sensibilities in such a controversy.

$* * * * *$

I am too much in earnest for either humility or vanity, but I do entreat those who hold the keys of life and death to listen to me also for this once. I ask no personal favor; but I beg to be heard in behalf of the women whose lives are at stake, until some stronger voice shall plead for them.

$$
* * * *
$$

If I am wrong, let me be put down by such a rebuke as no rash declaimer has received since there has been a public opinion in the medical profession of America; if I am right, let doctrines which lead to professional homicide be no longer taught from the chairs of ... great Institutions. Indifference will not do here .... Let the men who mould opinion look to it; if there is any voluntary blindness, any interested oversight, any culpable negligence, even, in such a matter, and the facts shall reach the public ear; the pestilence-carrier of the lyingin chamber must look to God for pardon, for man will never forgive him (19).

To what extent such passages simply flowed when this aroused mind was attached to a skilled pen, or whether Oliver Wendell Holmes on some occasions struggled every bit as much as other essayists, no one can say with certainty today. In many places, the 
introduction he added in 1855 to the otherwise unrevised, unedited 1843 version of his paper exhibits a self-conscious rhetorical style. Not only was the title more dramatic: Puerperal Fever as a Private Pestilence. Holmes also staked out his position for the past, in the present, and in the future:

The subject of this Paper has the same profound interest for me at the present moment as it had when I was first collecting the terrible evidence out of which, as it seems to me, the commonest exercise of reason could not help shaping the truth it involved.

$$
* * * * *
$$

I do not know that I shall ever again have so good an opportunity of being useful as was granted me by the raising of the question which produced this Essay. For I have abundant evidence that it has made many practitioners more cautious in their relations with puerperal females, and I have no doubt it will do so still, if it has a chance of being read, though it should call out a hundred counterblasts, proving to the satisfaction of their authors that it proved nothing. And for my part, I had rather rescue one mother from being poisoned by her attendant, than claim to have saved forty out of fifty patients to whom I had carried the disease.

$* * * * *$

I do not expect ever to return to this subject. There is a point of mental saturation, beyond which argument cannot be forced without breeding impatient, if not harsh, feelings towards those who refuse to be convinced. If I have so far manifested neither, it is well to stop here, and leave the rest to those younger friends who may have more stomach for the dregs of a stale argument (19).

Why Holmes publicly announced he intended to abandon the subject - despite his passionate insistence on its importance - is unclear. Here may be fuel for those who criticize him for his dilettantish approach to many subjects. This, too, must be explored.

\section{Conclusion}

Early in 2001, the author of the regular "Science Musings" column in the Boston Globe wrote an essay he called "A poet's kiss touches science." The argument in that column is not important here, but I thought of Holmes when this science writer reminded us that "Both poetry and science explore the mystery of the world" (36). 
Perhaps those who have difficulty with the variety encompassed by Oliver Wendell Holmes's total śuvre need to remember this; there may be more connection than meets the eye between the poet's sensibility and the mind of an anatomist cum physiologist or science reviewer.

Yet although the story was quite different during Semmelweis's life and the first few decades after his death, it is he who is now traditionally given pride of place in the puerperal fever story. Fair enough, though a writer who claims - on the strength of citations to Alexander Gordon and John Armstrong - that there "is now ample evidence" that Semmelweis was not first rather considerably oversimplifies the issue (7). On the other hand, those who want to place Holmes higher on the pedestal because he published his review essay before Semmelweis did his careful statistical analyses also reduce a complicated question to the easy-to-answer and not-very-interesting issue of priority (43). Many of the ideas promulgated by Holmes and Semmelweis, each in his very different way, had been and were being expressed by others $(2,10,11,31,44)$.

Why then focus on Semmelweis or - as I have here - on Holmes, at all? I earlier quoted Howard W. Haggard: "If Semmelweis had wielded the pen of Oliver Wendell Holmes his great discovery would have been adopted throughout Europe in the first twelve months after it was made" (12). Harvey Cushing turned this around: "If Oliver Wendell Holmes had been a visiting physician to the new Lying-in Hospital and had set about aggressively as did Semmelweis to prove his doctrine ...- what a different setting there might have been" (8).

Ah, yes, might have been. Even though I think both Haggard and Cushing are at least in part right, I am quite certain there is more to it than that. Among the important questions remaining are these: Why were Oliver Wendell Holmes and Ignác Fülöp Semmelweis believed - or not? How and why did they (compared to others before and after) become so nearly uniquely the heroes of the puerperal fever story as it is told by most medical historians today? The next step toward figuring this out about Holmes is to trace the path of influence of his essay; I will also make my own judgments about its relative merits compared to other essays that appeared around the same time (27). I will eventually undertake a similar examination of contemporary European journals to see whether I can - with greater precision and detail than has hitherto been achieved - trace the multiple paths of Semmelweis's influence (or lack thereof).

I am, perhaps above all, eager to see whether I can isolate the point at which Oliver Wendell Holmes became a "hero" of the campaign to save women's lives, so that a comparison can be made with the way Semmelweis was rescued from relative obscurity to become a hero for Hungary and the rest of the world. But getting a firm grip on Oliver Wendell Holmes will not be easy, this man of whom one biographer has 
said that he was a "poet, essayist, novelist, philosopher, wit, bon vivant, physician, scientist, and inventor ... the most interesting Renaissance man produced by Boston or any American city" (25).

\section{REFERENCES}

1. Am. J. of Med. Sciences 6, 260-262 (1843)

2. Armstrong J (1814): Facts and Observations Relative to the Fever Commonly Called Puerperal. Longman, Rees, Orme, and Brown, London (Constable and Co., Edinburgh).

3. Benedek I (1983): Semmelweis’ Krankheit. Akadémiai Kiadó, Vienna pp. 109, 110.

4. Carter KC: trans. and ed. of Semmelweis IP (1983): The Aetiology, Concept, and Prophylaxis of Childbed Fever. University of Wisconsin Press, Madison, Wisc.

5. Chambers WF: Oliver Wendell Holmes: Poet - Physician - Anatomist. Dartmouth Medical School Alumni Magazine 22, 20-23 (1980)

6. Cleavland CD: Lecture ticket. Dartmouth College Archives, Hanover, N. H.

7. Cook G: The cause and prevention of puerperal sepsis. J. RSM. 93, 280 (2000)

8. Cushing H (1940): From Tallow Dip to Television. In: The Medical Career. Little Brown, Boston (originally published 1931), pp. 51.

9. Downs RB (1982): Landmarks in Science. Libraries Unlimited, Littleton, Colo., pp. 232.

10. Gordon A (1795): A Treatise on the Epidemic Puerperal Fever of Aberdeen. GG and J Robinson, London.

11. Gortvay Gy, Zoltán I (1968): Priority Claims to the Semmelweis Doctrine. In: Semmelweis: His Life and Work. Akadémiai Kiadó, Budapest, pp. 208-217.

12. Haggard HW (1929): Devils, Drugs, and Doctors: The Story of the Science of Healing from MedicineMan to Doctor. Harper \& Bros., New York and London pp. 77.

13. Holmes OW (1884): Address at the One Hundredth Anniversary of the Founding of the Medical School of Harvard University. John Wilson and Son, Cambridge, Mass. pp. 6 and 15.

14. Holmes OW (1838): Boylston Prize Dissertations for the Years 1836-7. C. C. Little and J. Brown, Boston.

15. Holmes OW: Farewell Address ... to the Medical School of Harvard University. Boston Med. and Surg. J. 107, 529-534 (1882)

16. Holmes OW (1839): First Introductory Lecture. Dartmouth College Archives; original at Houghton Library, Harvard University, Cambridge, Mass. pp. 1, 3-6, 13; 10-11, 30 (photostat).

17. Holmes OW: Manuscript Poem (Unpublished, no page nos.) Delivered at Dartmouth College. Rare Books, Francis A. Countway Library, Harvard University, Boston, Mass.

18. Holmes OW (1830): Old Ironsides. In: Boston Daily Advertiser.

19. Holmes OW (1855): Puerperal Fever as a Private Pestilence. Ticknor and Fields, Boston. Introduction to, reprinted in: Medical Classics 1, no. 3, pp. 247-268.

20. Holmes OW (1840): Second Introductory Lecture, Dartmouth College Archives; original at Houghton Library, Harvard University, Cambridge, Mass. pp. 7ff., 1, 2; 11, 22-23; 24 (photostat).

21. Holmes OW (1867): Teaching from the Chair and at the Bedside: An Introductory Lecture. David Clapp \& Son, Boston, pp. 30.

22. Holmes OW: The Contagiousness of Puerperal Fever. New England Qrtly. J of Med. and Surg. 1, no. 4, 503-530 (1843)

23. Holmes OW: The Contagiousness of Puerperal Fever. Reprinted in: Medical Classics 1, no. 3, 211-243 (1843)

24. Howe MA DeW, Holmes OW (1932): In: Dictionary of American Biography, 22 vols., ed. Malone, D. Charles Scribner's Sons, New York, Vol. IX, pp. 169-176. 
25. Hoyt EP (1979): The Improper Bostonian: Dr. Oliver Wendell Holmes. William Morrow and Co., New York, pp. 12, 13, 16, 26-27, 31, 48, 85, 89, 90.

26. Huxley TH (1870): On Medical Education. In: Science and Education: Essays. D. Appleton and Co. New York, pp. 270 (1898)

27. Kneeland S: On the contagiousness of Puerperal Fever. Am. J. Med. Sciences 2, 454-463 (1846)

28. Lancaster HO: Semmelweis: a rereading of Die Aetiologie ... Part I: Puerperal sepsis before 1845. J. Med. Biol. 2, 12-21 (1994); and Part II: Medical historians and Semmelweis. J. Med. Biol. 2, 84-88 (1994)

29. Loudon I (1992): Death in Childbirth: An International Study of Maternal Care and Maternal Mortality, 1800-1950. Clarendon Press, Oxford.

30. Loudon I (2000): The Tragedy of Childbed Fever. Oxford University Press, Oxford, p. 88

31. Moore G (1836): An Enquiry into the Pathology, Causes, and Treatment of Puerperal Fever. S. Highly, London.

32. Morse JT (1896): Life and Letters of Oliver Wendell Holmes, 2 vols. Houghton Mifflin Co., Boston Vol. 1, pp. 159, 176.

33. Parsons GP: Puerperal Fever, Anticontagionists, and Miasmatic Infection, 1840-1860: Toward a New History of Puerperal Fever in Antebellum America. J. Hist. Med. and Allied Sciences 52, no. 4, 424-452 (1997)

34. Putnam CE: Pioneers of Puerperal Fever: The Unparallel Lives of Oliver Wendell Holmes and Ignác Fülöp Semmelweis (working title for the project, preliminary work on which was funded by a grant from the Wellcome Trust in London).

35. Putnam CE: To Promote Useful Science. Dartmouth Medicine 22, 22-29 (1997)

36. Raymo C: A poet's kiss touches science. Boston Globe, C2 (2001)

37. Scudder HE (1908): Biographical Sketch. In: The Complete Poetical Works of Oliver Wendell Holmes. Houghton Mifflin, Boston, p. xix.

38. Semmelweis IF (1861): Die Aetiologie, der Begriff und die Prophylaxis des Kindbettfiebers. Hartleben's Verlag, Pest-Wien-Leipzig.

39. Shattuck GC (1808): Three dissertations on Boylston Prize Questions for the years 1806 and 1807. Farrand, Mallory, \& Co., Boston.

40. Silló-Seidl G (1978): Die Wahrheit über Semmelweis. Ariston Verlag, Geneva.

41. Tilton EM (1947): Amiable Autocrat: A Biography of Dr. Oliver Wendell Holmes. Henry Schuman, New York, pp. 146, 172, 385.

42. Trustees Records, Dartmouth College, Vol. II, p. 347. Dartmouth College Archives, Hanover, N. H.

43. Weissmann G: Puerperal Priority. Lancet 349, 122-125 (1997)

44. White C (1777): A Treatise on the Management of Pregnant and Lying-in Women. Edward and Charles Dilly, London. 